\title{
The Impact of Fair Value Accounting on Information Asymmetry: Evidence from Jordanian Banking Sector
}

\author{
Mohammad Abdullah Fayad Altawalbeh ${ }^{1}$ \\ ${ }^{1}$ Business Faculty, Tafila Technical University, Tafila, Jordan \\ Correspondence: Mohammad Abdullah Fayad Altawalbeh Business Faculty, Tafila Technical University, Tafila, \\ Jordan.
}

Received: July 27, 2020

Accepted: August 11, $2020 \quad$ Online Published: August 20, 2020

doi:10.5539/ibr.v13n9p55

URL: https://doi.org/10.5539/ibr.v13n9p55

\begin{abstract}
This study aims at examining the impact of Fair value accounting measured by other comprehensive income on information asymmetry measured by the bid-ask spread in the Jordanian banking sector between 2010 and 2017. The study sample consisted of the thirteen commercial banks listed in Amman Stock Exchange, and panel data analyses were employed to test the study hypothesis, data for the study was gathered through the annual financial reports disclosed on Amman Stock Exchange. The findings revealed that fair value has a negative and significant impact on information asymmetry in the Jordanian commercial banks, indicating that fair value accounting supplies stakeholders with accurate and appropriate data and reflects the informational value of fair value numbers to investors.
\end{abstract}

Keywords: information asymmetry, fair value, IFRS13, accounting information

\section{Introduction}

Historical cost approach is accused of its inability to provide useful information in times of changing prices (Chambers, 1966, as cited by Deegan \& Unerman, 2012, p. 176). This is based on the assumption that historical cost depends on, this assumption states that money holds constant purchasing power, which may be the source for the following shortfalls:

- $\quad$ Problem of relevance in times of changing prices: Relevancy is one of the two primary qualitative characteristics introduced by the International Accounting Standard Board (IASB)/FASB conceptual framework. Relevant financial information, if it has predictive value and confirmatory value or both, can make a difference to the decisions made by users (IASB, 2010, QC6, 7). Therefore, is it relevant to report how much an asset was worth years ago?

- The problem of additively: The purchasing power of the dollar decreases as a result of inflation. Therefore, is it logical to add up assets acquired in different financial periods, given it seems like adding apples to oranges?

- Historical cost accounting tends to overstate the profit in the light of inflation, which might lead to operating capacity erosion.

- In times of inflation, historical cost accounting includes holding gains, which will distort current as well as the previous year's profit.

- Inadequate depreciation charges: One of the favorable side-effects of the process of depreciation is that it enhances the entity's ability to replace its non-current asset when the asset comes to the end of its estimated life. This is not possible if the historical cost is used as the base for calculating depreciation. As a result of the previous limitations, the fair value (FV) approach has been introduced as one of the various alternatives, which includes a radical departure from the traditional accounting system. In May 2011, the IASB issued International Financial Reporting Standard (IFRS) 13 fair value Measurement. The standard is effective from or after 1 January 2013. The standard defines fair value as "the price that would be received to sell an asset or paid to transfer a liability in an orderly transaction between market participants at the measurement date" (IFRS13 para9). The standard introduced valuation techniques, namely, the market approach, the cost approach, and the income approach. To enhance consistency, IFRS13 establishes a three-level hierarchy into which inputs used in the previous valuation techniques is classified. Level 1 includes unadjusted directly quoted prices in the 
case of identical asset or liability if an active market is available. Level 2 includes observable inputs other than quoted prices in Level 1, which include prices quoted for a similar asset or liability in an active market. If the market for the asset or liability in question is not active, then the quoted prices for identical assets and liabilities are included. Level 3 includes unobservable inputs, i.e., inputs for which market information is not available. Such inputs should use the best information available (IFRS13, Para: 76, 77, and 78).

An increasing number of international standards allow or require entities to use fair value for financial reporting purposes, previous studies suggest that using fair value accounting (FVA) might cope with the objectives of financial reporting as FV seems to give relevant information to the users of general purpose financial reports, (Barth et al., 2001). In the same context, some studies suggested the establishment of an IFRS committee to ensure the appropriateness of IFRS applications, specifically the fair value implementation (Shbeilat \& Al Harasees, 2018).

IASB has released a set of criteria that direct the use of fair value. IFRS 13 fair value Measurement offers a framework for fair value measurement. Proponents of FV argued that using FV accounting would enhance the relevancy as a qualitative characteristic of accounting information, which will help users make their decisions better. In contrast, critics to FV approach argued that the numbers derived through FV accounting might be confusing and misleading to users and could be used by an opportunistic management to influence the investor's behaviour regarding wealth transfer. Also, FV includes the problems of volatility and procyclicality (Vera, 2014). Although we maintain that transparency is of the essence, this paper aims to investigate whether FVA can enhance transparency by reducing the level of information asymmetry. The focus of our study would be on IFRS13 FV measurement as endorsed by IASB. We expect that our findings would confirm or refute our assumptions about the content and role of FV in reducing information asymmetry.

The conceptual framework for financial reporting 2010 issued by the IASB stated that investors and creditors require information that helps them determine the company's future net cash inflows, amounts, pacing, and volatility. (IASB, 2010, OB 3). It leads to our expectation that for the users, the FVA numbers might prove to be a tool to achieve the previous objective by enhancing the users' ability to forecast future cash flows including the amounts and timing of returns. Conversely, opponents of using FV claim that FV numbers are reliable only under steady economies (Liao et al., 2013). Critics also argue that previous studies revealed that FV has many shortcomings, which make it not only irrelevant but also might prove to be confusing. Therefore, critics call for the use of the cost model (Vera, 2014).

The current paper aims to examine the impact of using FVA on information asymmetry. To achieve this objective, the bid-ask spread was employed as the dependent variable. This would allow to directly capturing the impact of using FVA on information asymmetry. Bid-ask spread is a better measure of information asymmetry among market participants (Liao et al., 2013; Muller et al., 2011). If FV amounts have informational value, then their disclosure, we may expect, would reduce information asymmetry. Our paper depends on data of Jordanian commercial banks listed on Amman Stock Exchange (ASE) between 2010 and 2017. Consistent with previous studies (Fontes et al., 2018; Muller et al., 2011; Vergauwe \& Gaeremynck, 2019), the findings reveal that information asymmetry is negatively and significantly related to the disclosure of fair value numbers.

\subsection{Literature Review}

\subsubsection{Fair Value and Information Asymmetry}

Using a sample of European real estate firms over the 2007-2010 period, Vergauwe and Gaeremynck (2019) investigated whether measurement-related fair value disclosures minimize information asymmetry and if this decrease is accurate, utilizing various measures of information asymmetry. The findings indicated a negative relationship between the extent of fair value disclosures and the bid-ask range. However, they found no connection with two additional measures of information asymmetry (zero returns and price impact). Also, the analysis failed to find indications that organizations using model estimates benefit most specifically from that extra information.

Fontes et al. (2018) examined whether the use of fair value measurement in banking capital decreases the asymmetry of information and whether that is influenced by own recognition of credit risk benefits and loss. The results showed that measurements of fair value of assets reduce information asymmetries, and this decrease is more than twice as large if banks identify their own credit risks, gains, or losses. In addition to this, the study showed that banks that received comprehensive narrative disclosures on their own credit risk are less exposed to the bid-ask spread. Using a sample of agribusinesses listed in Australia, Colly et al. (2018) claimed to provide the first empirical evidence for the agricultural sector on the relevance of FVA. The study examined the forecasting power of the fair value of biological assets for future operating cash flows. The results revealed that 
fair value measurements of biological assets do not provide incremental forecasting power for future operating cash flows.

Weiss and Shon (2017) examined the impact of discretionary disclosure of the fair value of eighteen bank holding companies required by the Securities and Exchange Commission (SEC)'s Corporate Finance Division unique additional disclosure items in 2008 and for which an eight-factor index was established to evaluate the influence of such disclosures on information asymmetry.

Liao et al. (2013) examined whether US banks' fair value has any relation with information asymmetry in light of the financial crisis of 2008. The results showed a positive relationship between information asymmetry and fair value. In the context of usefulness of fair value in decision-making, Magnan (2013) found that using a fair value approach for the measurement in the financial reports has a negative impact on the cost of debt. This is consistent with the claim that FVA enhances the decision-making's usefulness. Muller et al. (2011) tested the effect of instituting fair value of non-current tangible assets on information asymmetry in the real estate industry in Europe, and the results revealed a high decrease in the level of information asymmetry by the obligatory adopters of fair value, and the voluntary adopters of fair value have a lower information asymmetry than the obligatory adopters. Laux and Leuz (2009) argued that fair value would increase transparency. Landsman (2007) argued that fair value figures are informative for users. Kothari and Lester (2011) argued that fair value information partially added to the financial crisis of 2008. In the same context, this paper aims at examining the impact of fair value on information asymmetry. Dignah et al. (2016) studied the impact of FVA on the price of equity capital of a sample of Asian banks. As banks charge a significantly larger amount of assets at fair value, the results indicated a significant reduction in the level of information asymmetry among mandatory fair value adopters. Besides, the findings showed similar results for quoted and unquoted assets.

Hui-Sung and Wei (2014) examined the effect of IFRS information asymmetry and corporate governance on the quality of accounting information. The results showed that the adoption of IFRS has reduced information asymmetry. In the same context, Surianti and Yadiati (2017) examined the impact of IFRS adoption, quality of accounting information and information asymmetry on cost of equity. The results showed that increased adoption of IFRS would reduce information asymmetry.

\subsubsection{IFRS in Jordan}

Jordan has begun to implement the full of IFRS standards (then called international accounting standards) without any modifications since 1997. For example, Article No. 6 of the Jordanian Banking law No.28 - for the Year 2000 - stated that the bank must be a public shareholding company and therefore, it should comply with all instructions issued by the Central bank of Jordan (CBJ) and Jordan Securities Commission. Furthermore, Article No. 14 explains that "the international accounting standards issued by the Board of International Accounting Standards are hereby adopted by all the parties subject to the Commission's monitoring and shall prepare their financial statements consistently therewith". Moreover, Regulations issued through the CBJ (for financial institutions) and by the Jordanian Insurance Commission (for insurance companies) require applying IFRS standards for regulated companies under their jurisdiction (IFRS, 2016).

This paper will add to the literature that considers the benefits and needs of the regulated financial reports, and it will extend studies that provide evidence about mandating the use of FVA. On the other hand, our study will provide evidence from the developing countries regarding the content and use of FVA.

\section{Research Methodology}

\subsection{Data and Sample Selection}

The fiscal year of a public shareholding company is determined by article (185) of the Jordanian company law to start on January first and end on the thirty first of December of the same year. Moreover, article (62) of the mentioned law requires public shareholding companies to prepare and disclose a fully audited set of financial statements as required by IFRS. This should be done within the first three months of the company's new fiscal year. Data required in our study were manually collected from the financial reports disclosed by the study sample on the ASE. Appendix A presents a list of the study sample, and our primary sample includes all the thirteen commercial banks listed on (ASE) between 2010 and 2017. All the banks in the sample provided the required data for the period selected for the study, i.e., from 2010 to 2017, leading to 520 firm-year observations. Table No.1 shows the study sample selection. 
Table 1. sample selection

Source. Jordanian Banks Guide, CBJ.

\begin{tabular}{|l|l|}
\hline Total number of banks operating in Jordan & 25 \\
\hline Exclude: Jordanian Islamic banks & $(4)$ \\
\hline Exclude: Foreign banks & $(8)$ \\
\hline Total number of banks in the sample (Commercial banks) & 13 \\
\hline
\end{tabular}

\subsection{Hypothesis Development}

Proponents of FVA as an alternative to the cost approach argue that assets and liabilities measured by fair value are more transparent, more relevant, and have a high level of reliability; and the reason is that the numbers under FV are quoted numbers (Ryan, 2008; Laux \& Leuz, 2009). Based on the previous discussions, we expect that the use of the FV approach in the financial statements will contribute to reducing the level of information asymmetry. Depends on the previous discussion, the study hypothesis will be as follows:

FVA has a significant impact on the level of information asymmetry in the Jordanian commercial banks.

\subsection{The Study Model}

Depending on previous studies (Fontes et al. (2018), Liao et al. (2013), Ball et al. (2012) and Muller et al. (2011)) the following general model was developed:

$$
\operatorname{SPREAD} D_{i, t}=\beta_{1} \mathrm{FVA}_{i, t}+\beta_{2} \mathrm{SIZE}_{i, t}+\beta_{3} \mathrm{LEV}_{i, t}+\beta_{4} \mathrm{ROI}_{i, t}+\varepsilon_{t}
$$

Where SPREAD $D_{i, t}$ indicates the bid-ask spread for bank I at time t. FVA ${ }_{i, t}$ is the FVA measure for bank I. while SIZE $_{i, t}$ is the size of bank I at time t. $\operatorname{LEV}_{i, t}$ is the leverage ratio for bank I at time $t$, and $\mathrm{ROI}_{i, t}$ is the return on investment for bank I at time t.

Information asymmetry is set as a dependent variable (Fontes et al., 2018; Ball et al., 2012; Muller et al., 2011). Subsequently, we measured information asymmetry using bid-ask spread which has been used widely as a proxy for information asymmetry (Muller et al., 2011). This paper defined bid-ask spread as the daily difference between the best ask price and the best bid price divided by the average of bid and ask as reported on ASE.

$$
\text { Daily Bid Ask spread } \mathrm{i}_{\mathrm{i}, \mathrm{t}}=\left(\frac{\text { BestAsk }_{i, t}-\text { BestBid }_{i, t}}{.5\left(\text { close }_{i, t}+\text { open }_{i, t}\right)}\right) * 100 \%
$$

Where

BestAsk $_{i, t}$ : The highest price offered to buy stock $\mathrm{i}$ in day $\mathrm{t}$.

BestAsk $_{i, t}$ : The lowest price required by an investor to sell stock $\mathrm{i}$ in day $\mathrm{t}$.

close $_{i, t}$ : The closing price of stock $\mathrm{i}$ in day $\mathrm{t}$.

open $_{i, t}$ : The opening price of stock $\mathrm{i}$ in day $\mathrm{t}$.

Following Liao et.al. (2013) and Muller et al. (2011), after calculating the daily bid-ask spread, bid-ask spread was averaged over a three-month window starting after the release of the financial reports in order to avoid any changes related to earnings announcement and to measure bid-ask spread for the three-month window to which FVA is related, rather than using the lag value of bid-ask spread.

This paper employed FVA as the main independent variable. Following Bratten et al. (2012) and Sodan, (2015), fair value was measured using the statement of comprehensive income approach. We calculated the amount of other comprehensive income (OCI) by the total adjustments amounts of fair value divided by the total of (OCI) and net income (NI)., where, OCI I,t ratio express the importance of OCI to the total of OCI and NI.

$$
\mathrm{OCI}_{\mathrm{I}, \mathrm{t}} \text { ratio }=\frac{\mathrm{OCIi,t}}{\mathrm{NIit+OCI} \mathrm{i}, \mathrm{t}} * 100 \%
$$

We control for the bank size measured by the natural logarithm of total assets, the financial leverage measured by debt ratio, and the return on investment (ROI) to control for a bank's performance. 


\section{Results}

\subsection{Summary of Statistics}

Table 2 below shows the descriptive statistics of the study's variables.

Table 2. Descriptive statistics

\begin{tabular}{|l|l|l|l|l|l|}
\hline & SPREAD & FVA & SIZE & LEV & ROI \\
\hline Mean & 1.9113 & 5.9113 & 9.3958 & 6.2239 & 1.2729 \\
\hline Median & 1.5282 & 5.1936 & 9.3274 & 5.9483 & 1.3824 \\
\hline Maximum & 13.0242 & 87.8889 & 10.6582 & 10.1054 & 2.5055 \\
\hline Minimum & 0.3374 & -385.6238 & 8.5349 & 3.5529 & -0.1659 \\
\hline Std. Dev. & 1.8992 & 42.3692 & 0.4355 & 1.2986 & 0.4882 \\
\hline Skewness & 0.3955 & -1.8954 & 0.9673 & 0.6937 & -0.5163 \\
\hline Kurtosis & 3.0932 & 6.3843 & 3.4613 & 3.0108 & 3.1994 \\
\hline Jarque-Bera & 4.8697 & 65.4277 & 25.8621 & 8.2701 & 5.6591 \\
\hline Probability & 0.0776 & 0.0000 & 0.0000 & 0.0159 & 0.0593 \\
\hline Observations & 104 & 104 & 104 & 104 & 104 \\
\hline Cross sections & 13 & 13 & 13 & 13 & 13 \\
\hline
\end{tabular}

With respect to Bid-Ask Spread (SPREAD), the mean of the dependent variable—-bid-ask spread—of the study sample during the period $2010-17$ is $1.91 \%$, and the median is $1.53 \%$. SPREAD ranged between $0.34 \%$ and $13 \%$ with a standard deviation of $1.9 \%$. These statistics indicate a relatively low level of information asymmetry among investors. However, the information asymmetry level differs significantly within the study sample. The mean of FVA, measured by OCI as a percentage is $5.91 \%$, which indicates the modest effect of fair value adjustments on the income of Jordanian banks. However, the maximum and minimum value of FVA indicates the existence of significant differences among Jordanian banks in terms of FVA.

The average size of Jordanian commercial banks during the study period was 9.39 logarithms (about JD 2487 million). Maximum, minimum and standard deviation indicate differences in the size among Jordanian banks. The average leverage ratio of Jordanian commercial banks during the period was 6.2 times.

ROI ranged between $-1.7 \%$ and $2.5 \%$, with a standard deviation of $0.5 \%$, which reflected the differences in profitability within the sample.

Figure 1 shows the time-series trends of the SPREAD between 2010 and 2017. The average value of SPREAD is $2.3 \%$ in 2010 , decreased to $1.6 \%$ in 2012, then increased to $2.1 \%$ in 2015 . Broadly speaking, the behaviour of SPREAD during the study period might indicate an increased concern regarding information risk.

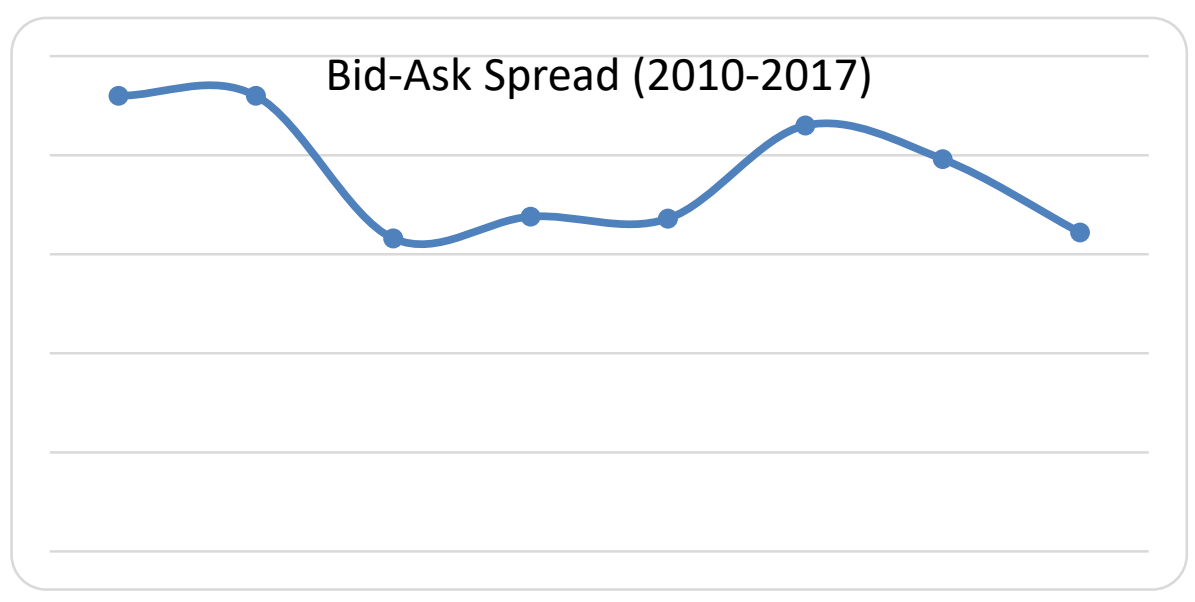

Figure 1. Bid-Ask Spread (2010-17)

Figure 2 shows the time-series trend of FVA between 2010 and 2017 measured by the OCI ratio; the increasing amounts of the independent variable starting at 2012 indicate the increasing importance of fair value adjustments. 


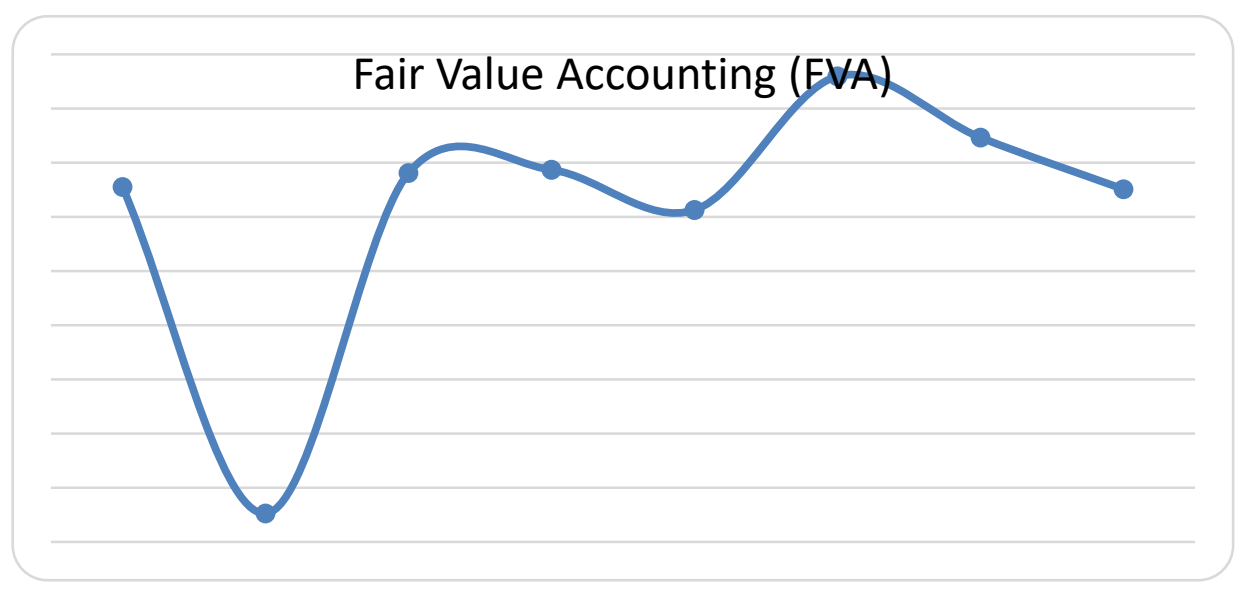

Figure 2. Fair Value Accounting (FVA) between 2010 and 2017

\subsection{Pearson Correlation Matrix}

Pearson correlation matrix is presented in Table 3 indicates a negative correlation between the dependent and independent variables. However, the correlations among independent variables are relatively low, indicating the absence of multicollinearity.

Table 3. Pearson correlation matrix

\begin{tabular}{|l|l|l|l|l|l|}
\hline & SPREAD & $F V A_{t-1}$ & SIZE $_{t}$ & $L E V_{t}$ & ROI $_{t}$ \\
\hline SPREAD & 1.000 & & & & \\
\hline$F V A_{t-1}$ & -0.283 & 1.000 & & & \\
\hline$S I Z E_{t}$ & -0.397 & 0.213 & 1.000 & & \\
\hline$L E V_{t}$ & 0.148 & -0.184 & 0.047 & 1.000 & \\
\hline ROI $_{t}$ & -0.188 & 0.217 & 0.058 & -0.356 & 1.000 \\
\hline
\end{tabular}

\subsection{Regression Analysis Results}

The data we collected spanned both time-series and cross-section, as such, and we employed the panel data regression and the generalized least square as an estimator. The use of panel data regression allows us to capture the changes in investors' behaviour over the study period. Moreover, it controls for unobserved heterogeneity and differences among the cross-section units and is seen to enhance the accuracy of parameter estimates due to greater degrees of freedom and less multicollinearity (Hsiao, 2002).

Table 4 presents the regression results. Consistent with previous studies (Fontes et al., 2018; Muller et al., 2011; Vergauwe \& Gaeremynck, 2019), we find that FVA is significantly negative (Coefficient $=-0.1011$; Prob $=$ 0.0000), which means that fair value numbers are considered of high quality to investors. In other words, the disclosure under IFRS13 would enhance the informational value of accounting numbers, which in turn motivates investors to decrease the bid-ask spread. SIZE and ROI show a significant negative direction (coefficient $=-$ 1.2437; Prob $=0.0000$; Coefficient $=-0.2393$; Prob $=0.0169$, respectively), indicating that larger and more profitable banks have lower spread than smaller and less profitable banks. These findings are consistent with previous studies because larger and profitable banks have higher trading volumes, which reduce the difference between the bid price and ask price. We failed to find a significant effect of leverage as banks are considered highly leveraged companies, thus the leverage ratio doesn't affect investors' concerns. 
Table 4. Regression results

\begin{tabular}{|l|l|l|l|}
\hline Variable & Coefficient & t-Statistic & Prob. \\
\hline C & 9.7533 & 7.5391 & $0.0000^{*}$ \\
\hline FVA & -0.1011 & -5.8008 & $0.0000^{*}$ \\
\hline SIZE & -1.2437 & -8.7269 & $0.0000^{*}$ \\
\hline LEV & 0.0006 & 0.7486 & 0.5586 \\
\hline ROI & -0.2393 & -2.4089 & $0.0169^{* *}$ \\
\hline \multicolumn{3}{|l|}{$*$ Sig at .01 level } & $* *$ sig at .05 level \\
\hline R-squared & 0.6279 & \\
\hline Adjusted R-squared & 0.5993 & \\
\hline S.E. of regression & 1.2068 & \\
\hline Durbin_Watson stat & 1.9146 & \\
\hline F_statistic & 33.2375 \\
\hline Prob (F-statistic) & 0.0000 \\
\hline \multicolumn{2}{|l|}{ SPREAD $D_{i, t}=\beta_{1} \mathrm{FVA}_{i, t}+\beta_{2} \mathrm{SIZE}_{i, t}+\beta_{3} \mathrm{LEV}_{i, t}+\beta_{4} \mathrm{ROI}_{i, t}+\varepsilon_{t}$} \\
\hline
\end{tabular}

*Using White (1980) heteroscedasticity standard errors and covariance.

\section{Conclusions}

Following the issuance of IFRS13: Fair Value Measurement, many researchers have examined the impact of FVA on different indicators regarding the usefulness and content of accounting information, including the impact of FVA on information asymmetry. This paper examines the impact of using FVA on information asymmetry with a focus on whether FVA, as mandated by IFRS13, would increase or decrease information asymmetry. data for the period 2010-2017 is obtained from thirteen Jordanian commercial banks listed on the ASE. This paper found evidence that FVA has a significant negative impact on information asymmetry, which reflects its informational value to investors. Although our findings suggest that mandating the use of fair value numbers is beneficial, this paper suffers from several limitations. First, the sample is limited to the banking sector only, which is characterized by strict governance regulations under the supervision of the Jordanian Central Bank. Therefore, we cannot generalize the results to other sectors. Second, we employed the bid-ask spread as a sole variable as the proxy for the information asymmetry which might not reveal the same results, for which, we suggest two future researches. The first one is to conduct a comparative study among sectors to capture the cross-sector differences, and the second is to examine the impact of the three fair value levels independently.

\section{References}

Ball, R., Jayaraman, S., \& Shivakumar, L. (2012). Mark-to-market accounting and information asymmetry in banks. Journal of Accounting \&Economics, 53, 136-66. https://doi.org/10.1016/j.jacceco.2011.11.005

Barth, M., Beaver, W., \& Landsman, W. (2001). The relevance of the value relevance literature for financial accounting standard setting: Another view. Journal of Accounting and Economics, 31(1), 77-104. https://doi.org/10.1016/S0165-4101(01)00019-2

Bratten, B., Causholli, M., \& Khan, U. (2012). Fair Value Accounting and the Predictive Ability of Earnings: Evidence from the Banking Industry. https://doi.org/10.2139/ssrn.2165996

Colly, L. Y., Wright, S., \& Evans, E. (2018). Is I love you guys fair value information relevant to investment decision-making: Evidence from the Australian agricultural sector? Australian Journal of Management, 43(4), 555-74. https://doi.org/10.1177/0312896218765236

Deegan, C., \& Unerman, J. (2012). Financial accounting theory (2nd ed.). London, UK: McGraw-Hill.

Dignah, A., Abdul, L., Radziah, A. K., Zulkefly, \& Abdul-Rahman, A. (2016). Fair value accounting and the cost of equity capital of Asian banks. Jurnal Pengurusan, 48, 125-35. https://doi.org/10.17576/pengurusan-2016-48-10

Fontes, J. C., Panaretou, A., \& Peasnell, K. V. (2018). The impact of fair value measurement for bank assets on information asymmetry and the moderating effect of own credit risk gains and losses. The Accounting Review, 93(6), 127-47. https://doi.org/10.2308/accr-52070

Hsiao, C. (2002). Analysis of panel data (2nd ed.). Cambridge, NY: Cambridge University Press.

Hui-Sung, K., \& Wei, T. (2014).The effect of IFRS information asymmetry and corporate governance on the quality of accounting information. Asian Economic and Financial Review, 4(2), 226-56. 
IFRS. (2016). IFRS Application Around the World Jurisdictional Profile: Jordan. Retrieved from https://www.ifrs.org/use-around-the-world/use-of-ifrs-standards-by-jurisdiction/jordan/\#commitment

Kothari, S. P., \& Lester, R. (2011). The Role of Accounting in the Financial Crisis: Lessons for the Future. https://doi.org/10.2139/ssrn.1972354

Landsman, W. R. (2007). Is fair value accounting information relevant and reliable? Evidence from capital market research. Accounting and Business Research, 37(1), 19-30. https://doi.org/10.1080/00014788.2007.9730081

Laux, C., \& Leuz, C. (2009). The crisis of fair-value accounting: Making sense of the recent debate. Accounting, Organizations and Society, 34, 826-34. https://doi.org/10.1016/j.aos.2009.04.003

Liao, L., Kang, H., Morris, Richard D., \& Tang, Q. (2013). Information asymmetry of fair value accounting during the global financial crisis. Journal of Contemporary Accounting and Economics, 9(2), 221-36. https://doi.org/10.1016/j.jcae.2013.10.001

Muller, K., Riedl, E., \& Sellhorn, T. (2011). Mandatory FVA and information asymmetry: Evidence from the European real estate industry. Management Science, 57, 1138-53. https://doi.org/10.1287/mnsc.1110.1339

Palea, V. (2014). Fair value accounting and its usefulness to financial statement users, Journal of Financial Reporting and Accounting, 12(2), 102-16. https://doi.org/10.1108/JFRA-04-2013-0021

Ryan, S. G. (2008). Accounting in and for the subprime crisis. The Accounting Review, 83(3), $1605-39$. https://doi.org/10.2308/accr.2008.83.6.1605

Shbeilat, M. K., \& Al Harasees, M. N. (2018). Do listed companies need an IFRS committee beside audit committee? International Journal of Academic Research in Accounting, Finance and Management Sciences, $8(2), 8-18$.

Šodan, S. (2015). The Impact of Fair Value Accounting on Earnings Quality in Eastern. https://doi.org/10.1016/S2212-5671(15)01481-1

Surianti, M., \& Yadiati, W. (2017). The impact of IFRS adoption, quality of accounting information and information asymmetry on cost of equity (Analysis in Indonesia stock exchange as emerging market). International Business Management, 11(12), 2138-50.

Vergauwe, S., \& Gaeremynck, A. (2019). Do measurement-related fair value disclosures affect information asymmetry? Accounting and Business Research, 49(1), 68-94. https://doi.org/10.1080/00014788.2018.1434608

Weiss, R., \& Shon, J. (2017). Information asymmetry and voluntary SFAS 157 fair value disclosures by bank holding companies during the 2007 financial crisis. Accounting Perspectives, 16(3), 169-203. https://doi.org/10.1111/1911-3838.12144

\section{Appendix}

\begin{tabular}{|l|l|l|l|}
\hline & \multicolumn{1}{|c|}{ Bank's Name } & Establishment Date & Bank's Code \\
\hline 1 & Arab Bank & 1930 & ARBK \\
\hline 2 & Arab Banking Corporation (Jordan) & 1989 & ABCO \\
\hline 3 & Bank of Jordan & 1960 & BOJX \\
\hline 4 & Cairo Amman Bank & 1960 & CABK \\
\hline 5 & Capital Bank of Jordan & 1996 & EXFB \\
\hline 6 & Jordan Commercial Bank & 1978 & JCBK \\
\hline 7 & Jordan Kuwait Bank & 1977 & JOKB \\
\hline 8 & Jordan Ahli Bank & 1956 & AHLI \\
\hline 9 & The Housing Bank for Trade \& Finance & 1974 & THBK \\
\hline 10 & Arab Jordan Investment Bank & 1978 & AJIB \\
\hline 11 & Investbank & 1989 & INVB \\
\hline 12 & Société Generale de Banque /Jordanie & 1993 & SGBJ \\
\hline 13 & Bank al Etihad & 1991 & UBSI \\
\hline
\end{tabular}

\section{Copyrights}

Copyright for this article is retained by the author(s), with first publication rights granted to the journal.

This is an open-access article distributed under the terms and conditions of the Creative Commons Attribution

license (http://creativecommons.org/licenses/by/4.0/). 